2 DR. DEBORAH BOWER (Orcid ID : 0000-0003-0188-3290)

5 Article type : Research Article

10 Deborah S. Bower ${ }^{1,2}$, Laura A. Brannelly ${ }^{3}$, Cait A. McDonald ${ }^{4}$, Rebecca J. Webb ${ }^{5}$, Sasha E.

11 Greenspan ${ }^{6}$, Mathew Vickers ${ }^{1}$, Michael G. Gardner ${ }^{7,8}$, Matthew J. Greenlees ${ }^{9}$.

\title{
12 Affiliation:
}

$13{ }^{1}$ College of Science and Engineering, James Cook University, Townsville, 4811, Queensland,

14 Australia, deborah.bower@gmail.com, +61(0) 413334587, (Corresponding author)

$15{ }^{2}$ School of Environmental and Rural Science, University of New England, Armidale, New South

16 Wales 2350, Australia.

$17{ }^{3}$ Department of Biological Sciences, University of Pittsburgh, Pittsburgh, Pennsylvania 15260,

18 United States of America

$19{ }^{4}$ Department of Ecology and Evolutionary Biology, Cornell University, Ithaca, New York

20 14853, United States of America

$21{ }^{5}$ College of Public Health, Medical and Veterinary Sciences, James Cook University,

22 Townsville, Queensland 4811, Australia

$23{ }^{6}$ Department of Biological Sciences, University of Alabama, Tuscaloosa, Alabama 35487 ,

24 United States of America

$25{ }^{7}$ College of Science and Engineering, Flinders University, GPO Box 2100, Adelaide, South

26 Australia 5001, Australia

$27{ }^{8}$ Evolutionary Biology Unit, South Australian Museum, North Terrace, Adelaide 5000 South

28 Australia, Australia.

This is the author manuscript accepted for publication and has undergone full peer review but has not been through the copyediting, typesetting, pagination and proofreading process, which may lead to differences between this version and the Version of Record. Please cite this article as doi: $\underline{10.1111 / \text { aec. } 12695}$

This article is protected by copyright. All rights reserved 
${ }^{9}$ School of Life and Environmental Sciences, University of Sydney, New South Wales 2006

30 Australia

31 Key words:

32 Pathogen, Parasite, Disease, Behaviour, Physiology,

33 Abstract:

34 A great diversity of parasites, from viruses and bacteria to a range of remarkable eukaryotic

35 organisms, exploit reptile and amphibian hosts. Recent increases in the emergence of infectious

36 disease have revealed the importance of understanding the effects of interactions between hosts

37 and their parasites. Here we review the effects of parasite infection on a range of demographic,

38 behavioural, genomic and physiological factors in reptile and amphibian species. Reviewing

39 these parasite roles collectively, and prioritising areas for research, advances our ecological

40 understanding and guides direction for conservation in a time of rapid species decline. Poorly

41 resolved systems include Gymnophionan amphibians and Crocodilian hosts, in addition to viral

42 and bacterial parasites. Future research should seek to understand processes enabling population

43 recovery and examining synergistic interactions of parasites with fragmentation, climate change

44 and other processes that threaten species persistence.

\section{Introduction}

48 Parasites have been historically underrepresented in ecological studies but are slowly gaining

49 recognition. The difficulties involved in visual identification and classification (McManus and

50 Bowles 1996), lack of statistical power owing to small sample size, and poor preservation of

51 hosts for subsequent examination, has hindered our ability to quantify parasite and thus

52 incorporate their effects into ecological research. Perhaps owing to the comparative ease of

53 accounting for competing ecological processes such as those in predator-prey systems, parasite

54 systems have received comparatively less attention (Raffel et al. 2008). Recent advances in

55 genomic technology and recognition of the severe impacts of parasites have catalysed research

56 that was not previously possible or prioritized (Huggins et al. 2017; McKnight et al. 2017).

58 Reptiles and amphibians are a paraphyletic group of vertebrates (Field et al. 2014) united by

59 their ectothermic physiology and primarily terrestrial habits. Unlike taxa that serve as important 
60 human food resources such as fish, or aesthetically appealing groups such as mammals and birds, 61 amphibians and reptiles (e.g. snakes, lizards and frogs) are less valued by society (Czech et al.

62 1998); this is reflected by their disproportionately lower representation in published literature

63 (Hecnar 2009). Understanding reptiles and amphibians is important because they are species rich 64 with almost 8000 described amphibian species and over 10000 reptile species. They can obtain

65 high biomass and play important roles in the ecosystem including as prey, consumers,

66 pollinators, dispersers, nutrient cycling and bioturbators of soil (Godínez-Álvarez 2004; Iwai and

67 Kagaya 2007; Lovich et al. 2018; Sin et al. 2008). Reptiles and amphibians have become

68 increasingly vulnerable to extinction and thus research focused on understanding threatening

69 factors to aid in conservation has recently become a priority (Gibbon et al. 2000; Meredith et al.

70 2016).

72 In conservation, the paucity of ecological knowledge in the context of amphibian disease ecology 73 became evident during the global amphibian decline (Collins and Storfer 2003). Biologists were

74 not prepared for disease-induced declines, and pioneering studies on parasites became invaluable

75 to understand host physiology and behaviour, as well as broad ecological processes. The

76 increased emergence of infectious disease over the past two decades has only served to

77 consolidate the importance of understanding the ecological interactions between hosts and

78 parasites (Bower et al. 2017b). As the importance of research that quantifies the effects of

79 parasites is increasingly recognised, a review of these studies is timely.

81 A leader in this field was the late Professor Michael Bull, and his pioneering work arises

82 repeatedly throughout the various subtopics of our review. Here we aim to pay homage to the

83 foresight and dedication of Michael Bull by demonstrating the importance of parasites in the

84 ecology of reptiles and amphibians. We draw from the available literature to highlight the

85 diversity and extent to which parasites and hosts are intertwined in fundamental ecological

86 processes. Specifically, we focus on summarising our knowledge of parasite impacts on reptiles

87 and amphibians, and highlight challenges we face in continuing to unravel these complex

88 relationships.

89

90 2. Diversity of parasites 
91 The term parasite encapsulates a taxonomically diverse selection of organisms. They are

92 physiologically dependent on other organisms and, unlike predators, have higher reproductive

93 potential than their host (Crofton 1971). Here we take the ecological definition of parasites as

94 'any organism that decreases the fitness of its host by infecting it' and include both micro-

95 parasites (e.g., viruses and bacteria) and macro-parasites (e.g., worms) (May and Anderson 1990;

96 Méthot and Alizon 2014). Parasites can have a range of effects that differ according to host

97 species, host physiology, host behaviour and environment. There are several taxa of parasites

98 that use reptile (crocodiles, turtles, tuatara, amphisbaenians, lizards and snakes) and amphibian

99 (frogs, salamanders and caecillians) hosts.

100

101

2.1 Viruses

102 Owing to their miniscule size, viruses were not described until long after their effects were

103 known and their role in ecology remains poorly understood. They are intracellular parasites and

104 cannot replicate outside a host. Transmission can occur directly through contact with infected

105 hosts or reservoir surfaces, or via vectors such as ticks and mosquitoes (Marschang 2011).

106 Spanning an extreme spectrum of effects, viruses can range in impact from appearing benign in

107 populations to causing mass mortality events. They also vary from being highly specific to broad

108 in host range and can be zoonotic (transmissible from animals to humans), though pathogenicity

109 toward different hosts is not well understood for most viruses (Ariel 2011). Despite their ability

110 to significantly hinder conservation efforts, some suspected pathogenic viruses remain

111 unresolved as causal agents (e.g. chelonid fibropapilloma associated herpesvirus). The recent

112 characterization of the shingleback nidovirus (O’Dea et al. 2016) highlights just how little we

113 know about virology in comparatively well-studied reptile species, in this case sleepy lizards

114 (Tiliqua rugosa), variously known as shinglebacks, or bobtails. Associated with the disease

115 syndrome coined 'bobtail flu', globally this is the first report of such a virus in a lizard. Other

116 viruses (e.g ranavirus) have been the subject of ecological studies because they threaten

117 populations of reptiles and amphibians and in these cases, much has been documented on

118 transmission and susceptibility (Gray et al. 2009).

119

$120 \quad 2.2$ Bacteria

This article is protected by copyright. All rights reserved 
121 Bacteria are receiving increasing attention for the role they may play in host ecology.

122 Exploration into the function of microbiomes has accelerated this research field, owing in part to

123 the inhibitory effects of bacteria on other pathogens such as the amphibian chytrid fungus

124 (Batrachochytrium dendrobatidis, Bd) (Jani and Briggs 2014). From an ecological perspective,

125 the ubiquitous nature of bacteria make them problematic for detection and quantification, and

126 understanding when bacteria are pathogenic and under what circumstances continues to

127 challenge researchers (Ramakrishnan et al. 1997). Species that cannot be cultured in vitro make

128 Koch's postulates difficult to fulfill though sequencing is a powerful tool that is allowing us to

129 unravel interactions among bacteria that we could not previously examine (Byrd and Segre

130 2016). We do not know how bacteria interact in wild populations for many species, despite their

131 ability to cause bacterial septicemia in captive populations (e.g. Aeromanas hydrophila, (Mauel

132 et al. 2002; Pasquale et al. 1994)), and the lack of histopathological confirmation leaves

133 uncertainty surrounding the cause of some wild die-offs. Pioneering research has demonstrated

134 the importance of social networks (Bull et al. 2012) and reservoir species in transmission and

135 population biology of specific bacteria (Giery and Ostfeld 2007). Bacterial zoonotic diseases

136 have been the subject of some experimental ecological studies, e.g., those demonstrating

137 antibiotic resistance in human-disturbed sites (Wheeler et al. 2012). Salmonella spp. infections

138 can potentially spill over in the pet trade (Whiley et al. 2017), but the threat from wildlife

139 appears low (Parsons et al. 2010).

\subsection{Blood (Erythrocytic) parasites}

142 Blood parasites are a paraphyletic group of eukaryotic organisms that occur in the blood stream

143 of hosts (e.g. phylum Apicomplexa). Some of the most extensive long term ecological studies

144 have quantified the effects of blood parasites on the behavior and physiology of squamate hosts

145 (Otero et al. 2017; Schall 1982). These have incorporated the paradoxical trade-off in sacrificing

146 parasitic defenses to increase fitness opportunity, only to pay associated costs of increased

147 parasite intensity (Bouma et al. 2007). Generally, lizards and blood parasites (e.g Malaria) have

148 proved useful models to address evolutionary questions of diversification and adaptation.

149

150 Despite comprehensive ecological studies on squamates and blood parasites, amphibians have

151 received relatively little attention. Recent work demonstrating sexual differences in trypanosome 
152 prevalence (Trypanosoma tungarae) in túngara frogs (Physalaemus pustulosus) suggests

153 interesting ecological interactions are at play; frog-biting midges that find their host by male

154 mating calls may be a vector in this system (Bernal and Pinto 2016). The ecological role of other

155 parasites such as Perkinsea-like protists also correlate with mass declines and disease of tadpoles,

156 and are widely distributed throughout the globe (Chambouvet et al. 2015). Other parasites such

157 as Mesomycetozoeans (fungal-like opisthokonts) are little known (Rowley et al. 2013) though

158 declines of at least one frog species are correlated with an outbreak (Di Rosa et al. 2007). As

159 technologies are applied to these understudied groups, further relationships between host and

160 parasites are likely to be revealed.

161

162 2.4 Fungi

163 The global emergence of fungal diseases and associated mass die-offs in a diversity of reptile

164 and amphibian species has brought mycoses (diseases caused by fungi) to the forefront of

165 research and conservation. The number of extirpation events caused by fungi has increased in

166 recent decades, and many losses of amphibian species are included in these events (Fisher et al.

167 2012). The emergence of two distinct species of chytrid fungi (Batrachochytrium dendrobatidis

168 and B. salamandrivorans) has caused multi-continental amphibian declines, which led to an

169 explosion in ecological studies incorporating these parasites (Bower et al. 2017a). Additionally,

170 an emerging fungal disease (associated with Ophidiomyces ophiodiicola) causing epidemics in

171 snakes is receiving increasing attention (Allender et al. 2015). Marine turtles have also suffered

172 disease associated with Fusarium spp. infection causing mass mortality in nests, particularly in

173 stressful environmental conditions (Sarmiento-Ramírez et al. 2010). While other potentially

174 lethal fungi have been identified (e.g. Mucor amphibiorum, Paranannizziopsis australasiensis),

175 research has been restricted to quantifying prevalence (Masters et al. 2016; Speare et al. 1994).

176 A potentially deadly fungus, Lecanicillium spp., was diagnosed in a captive colony of

177 endangered Guthega skinks (Liopholis guthega) causing cutaneous and systemic mycosis and

178 provided the first report of this infection in reptiles. Beyond these few examples, ecology of

179 fungal pathogens in reptiles and amphibians is little known.

180

1812.5 Animals

182 Endoparasites

This article is protected by copyright. All rights reserved 
183 A diversity of animals parasitise reptiles and amphibians. Myxosporean parasites (Cnidarians)

184 are mostly known from fish, but will also infect reptile and amphibian species (Eiras 2005).

185 Comprehensive ecological studies detailing prevalence and effects in wild populations are

186 lacking (Okamura et al. 2018), though myxosporean parasites can reach high loads and cause

187 disease in captive frogs (Hartigan et al. 2011), and they may have emerged in distribution

188 recently (Hartigan et al. 2010).

189 Helminths such as pentastomids (respiratory tract), cestodes, trematodes, nematodes, and

190 acanthocephalans are a diverse group of animals clustered together by their worm like

191 appearance and featuring as important parasites in reptile and amphibian health (Koprivnikar et

192 al. 2012). Studies of parasitic worms have moved beyond taxonomic description to incorporation

193 into occupancy modelling (Campião et al. 2012), behaviour (Gyawali et al. 2013; Pfennig and

194 Tinsley 2002), and physiological costs of infection (Goater and Ward 1992), as well as how

195 infection interacts with the environment (Soliman 2012).

Ectoparasites

197 Studies on the behavioural and physiological interactions of ectoparasites such as ticks and mites

198 in reptile and amphibian ecology have also been extensive, forming a substantial component of

199 the life work of Michael Bull (Godfrey and Gardner 2017). Ticks (Bothriocroton hydrosauri) on

200 sleepy lizards (T. rugosa) and other bluetongues (T. spp.) have been identified as vectors for the

201 bacterial agent causing spotted fever (i.e. the bacteria Rickettsia sp.) (Stenos et al. 2003; Whiley

202 et al. 2016). Flies and mosquitoes have also received some attention in ecological studies, both

203 as direct parasites and vectors (Bernal et al. 2007). Additionally, the ecological interactions of

204 leeches have been explored in salamanders (Lunghi et al. 2018) and turtles, which can harbor

205 high densities of over 150 leeches on a single turtle (Graham et al. 1997). They further act as

206 vectors for blood parasites e.g. for haemogregarines and trypanosomes (Siddall and Desser

207 1992).

208

209

\section{Environmental Interactions}

210 The environment of the host can strongly influence parasite dynamics. Reptiles and amphibians

211 are ectotherms, and as such, their physiological processes are governed by ambient temperature. 
212 Behavioural thermoregulation is a consequence of parasite infection in both reptiles (Schall \&

213 Sarni 1987, Main \& Bull 2000) and amphibians (Lefcort \& Eiger 1993, Lefcort \& Blaustein

214 1995, Richards-Zawacki 2009). Their immune system is at the mercy of environmental

215 conditions, and sub-optimal temperature can cause immunosuppression in many species. For

216 example, in cold stunned Kemp's ridley sea turtles (Lepidochelys kempii) in Massachusetts, most

217 of the pathological changes observed were associated with bacteria and or fungi. These were

218 suspected to be opportunistic infections due to host immunosuppression caused by the cold

219 temperatures (Innis et al. 2009). Prolonged exposure to low temperatures during hibernation

220 resulted in weakened immune systems in leopard frogs (Lithobates [Rana] pipiens) (Cooper et

221 al. 1992), and a lizard called the sandfish skink (Scincus scincus) had reduced lymphoid tissues

222 and immune response in winter (Hussein et al. 1979). In other cases, suboptimal temperatures

223 may elicit an increased immune response resulting in better resistance to disease. Green Tree

224 frogs (Litoria caerulea) experimentally acclimated to low temperatures had lower infection

225 intensities when exposed to the amphibian chytrid fungus (B. dendrobatidis) than those

226 acclimated to higher temperatures (Greenspan et al. 2017b). The individuals exposed to sub-

227 optimal temperature were better able to fight the pathogen because their immune parameters

228 were already adjusted to cope with the challenging environmental conditions. The cool-exposed

229 individuals had a higher neutrophil:lymphocyte ratio, a response also seen in leopard frogs $(L$.

230 pipiens) (Maniero and Carey 1997).

232 Along with temperature, other external factors can influence the immune system of hosts and

233 their ability to resist infection. Juvenile leopard frogs (L. pipiens) experimentally exposed to

234 agricultural pesticides experienced lower lymphocyte proliferation which have a central role in

235 pathogen defense. Higher nematode burdens (Christin et al. 2003) and trematode infection can

236 increase exposure and susceptibility by augmenting intermediate snail hosts and reduce liver

237 eosinophil (disease-fighting blood cells) counts, indicative of a reduced immunity (Rohr et al.

238 2008). In addition, UVB radiation causes immunosuppression in amphibians and increases

239 susceptibility to disease (Little and Calfee 2010). Heavy metal toxicity can also cause

240 immunosuppression. For example, mercury concentrations were correlated with reduced

241 lymphocyte proliferation and activity in Loggerhead sea turtles (Caretta caretta) (Day et al.

242 2007). The viral disease 'green turtle fibropapillomatosis' affects all sea turtle species, and 
243 infected individuals also present with reduced lymphocyte proliferation and activity, suggesting

244 that heavy metal contamination such as mercury may make turtles more susceptible (Grillitsch

245 and Schiesari 2010).

247 Stress-induced physiological changes may increase the incidence of disease in reptiles and

248 amphibians. Environmental stressors such as desiccation of ponds cause tadpoles to

249 metamorphose faster, and this can have a trade off in terms of immunocompetence. Wood frog

250 (Lithobates sylvaticus) tadpoles exposed to experimental desiccation have fewer lymphocytes

251 and reduced responses to immune challenge after metamorphosis (Gervasi and Foufopoulos

252 2008). Newly metamorphed amphibians are disproportionally more vulnerable to the amphibian

253 chytrid fungus (B. dendrobatidis) infection, so immune suppression due to environmental

254 stressors can have a dramatic effect on susceptibility (Gervasi and Foufopoulos 2008). The

255 effects of stress on host susceptibility may also have conservation implications. For example, the

256 stress of capture and release into an unfamiliar environment caused a higher rate of disease in

257 translocated Timber Rattlesnakes (Crotalus horridus) compared to resident animals (Reinert and

258 Rupert Jr 1999). High densities can reduce immunity and this can be age dependent within a

259 species. For example, higher densities of adults of the lizard (Zootoca vivipara) experienced

260 increased local inflammation and high densities of tick infestation (Ixodes ricinus) whereas

261 yearlings did not experience inflammation or increased tick infestation (Mugabo et al. 2015).

262 Habitat features can also affect parasites differently. In a Mediteranean lizard (Psammodromus

263 algrius), the prevalence and infection load of blood parasites was higher in a high elevation

264 deteriorated habitat whereas prevalence and infection load of ticks (Ixodes sp) showed the

265 reverse pattern (Carbayo et al. 2018).

\section{Behaviour}

269 Much attention has been devoted to understanding the ways in which parasites manipulate their

270 hosts following infection (Finnerty et al. 2018; Klein 2003; Moore 1984; Smith Trail 1980).

271 Where the effects of parasites on hosts are deleterious, behavioural strategies that help the host

272 avoid initial infection should be favoured by evolution. Amphibians can recognise and avoid

273 both physical and chemical cues from some potential parasites. Frogs adopt various strategies 
274 such as foot-stomping, jumping, and wiping their hands over their bodies to prevent mosquito 275 bites, which minimises transmission of mosquito-borne parasites (Ferguson and Smith 2012).

276 Grey tree frogs Dryophytes [Hyla] versicolor discriminated between water bodies based not only

277 on the presence and density of a gastropod vector that carries a trematode parasite of their

278 tadpoles, but also on whether or not the snails were infected, laying less frequently and fewer

279 eggs in treatments with a higher likelihood of infection (Kiesecker and Skelly 2000).

280 There is species-specific variation in the behaviour of tadpoles toward the presence of

281 trematodes (Echinoparyphium sp.) (Koprivnikar et al. 2014). Permanent pond breeding frogs that

282 were more likely to encounter trematodes (Echinostoma spp.) modified their activity in the

283 presence of these parasites. Conversely, ephemeral breeding frog species that encountered less

284 trematodes also lacked the behavioural response, suggesting selection may occur on such

285 behavioural traits (Szuroczki and Richardson 2012). Parasite avoidance behaviour is complex

286 and interacts with predators, whereby tadpoles (L. pipiens) preferred areas without trematodes

287 (Ribeiroia ondatrae) unless their alternative was predator exposure by larval odonates

288 (Koprivnikar and Penalva 2015). American toad tadpoles (Bufo americanus) fleed from the

289 touch of a trematode (Echinostoma sp.) (Taylor et al. 2004), and tadpoles adopted behaviours

290 that influenced the site in which infection occurred and thus decreased the pathological

291 consequences of infection (Kiesecker et al. 1999; Sears et al. 2013). Selection against

292 cannibalism is thought to have evolved as a behaviour to minimise parasite transmission between

293 intraspecific hosts. For example, larval tiger salamanders (Ambystoma tigrinum) avoided preying

294 on conspecifies with bacterial infection (Clostridium sp. bacteria) (Pfennig et al. 1998; Pfennig

295 et al. 1991). In other cases tadpoles (Pseudacris regilla and Anaxyrus boreas) did not adopt

296 behaviours to minimise transmission by snails infected with a trematode parasite ( $R$. ondatrae),

297 but once infected, decreased their activity and escape distance (Preston et al. 2014).

298 Interestingly, the same study showed two less virulent trematodes (Echinostoma sp. and Alaria 299 sp.) caused no such effects.

301 Surprisingly, few studies have revealed behaviours that minimise or reduce potential

302 transmission of ectoparasites in reptiles, despite the negative physiological consequences (Aubret

303 et al. 2014; Biaggini et al. 2009; Godfrey et al. 2006). Although one exception in the usually

304 monogamous sleepy lizard (T. rugosa) showed that males that are abandoned by females 
between mating seasons have higher tick loads than males that retain their partners, thereby

306 reducing infection potential for females (Bull and Burzacott 2006). As many endoparasites of

307 reptiles are transmitted via their prey, the potential for avoidance may be difficult. Notably,

308 several studies on blood parasites (Hepatozoon sp.) in snakes that demonstrated negative effects

309 on nutritional status, reproduction and survival (Madsen et al. 2005) revealed little effect on

310 behaviour. Keelback snakes (Tropidonophis mairii) infected with parasites (Family:

311 Haemogregarinidae and Gnathostomidae) had similar performance (e.g. 'sprint' speed) and

312 fitness measures (e.g. escape distance) to uninfected individuals (Brown et al. 2006).

314 Many of the studied behavioural changes in hosts are investigated as a limited single species

315 comparison (Damas-Moreira et al. 2014; Daniels 1985; Oppliger et al. 1996). These studies

316 often explore only the alteration in behaviour without examining underlying mechanisms.

317 However, there are a number of notable studies that explore complex interactions that note both

318 changes in behaviour of the host and the consequences of these changes for ecology and

319 evolution. These complex interactions have often been demonstrated using lizards, specifically

320 Lacerta, Anolis and Sceloporus spp., as model organisms. These studies demonstrated that

321 Plasmodium sp. infection altered male social behaviour (Schall 1982), in part due to altered

322 thermoregulatory and perching behaviour of hosts (Schall and Sarni 1987). Similarly,

323 Plasmodium sp. infection altered the outcome of competitive interactions between two species of

324 lacertid lizard, ultimately playing a critical role in determining the distribution of each species on

325 a landscape scale (Schall 1992; Schall and Vogt 1993). Finally, ectoparasites (ticks Aponomma

326 hydrosauri and Amblyomma limbatum) can affect simple behaviours in sleepy lizards (T. rugosa)

327 such as the time spent basking, moving and ultimately dispersing (Main and Bull 2000) but

328 under natural conditions these hosts appear adapted to the ticks and movement is more strongly

329 explained by sex and body condition independent of ticks (Taggart et al. 2018). Effects can be

330 intergenerational, in female common lizards (Z. vivipara), parasitism by mites (Family:

331 Lealapidae) effected the dispersal behaviour of the offspring (Sorci et al. 1994). Such studies

332 highlight the importance of parasites in shaping behaviours that intricately influence the ecology

333 of animals and suggest that any ecological study that wishes to quantify behaviour should

334 attempt to account for possible influences of parasites. 
335 Some of the most detailed behavioural studies have arisen as a result of specific threats to the

336 persistence of species, thus much research has been invested in understanding the amphibian

337 chytrid fungus (B. dendrobatidis) (Pounds et al. 2006). The disease (chytridiomycosis) caused by

338 the fungus (B. dendrobatidis) has, in some cases, selected for species and individuals that behave

339 in a particular way. For example, the thermal history of different rainforest frog species strongly

340 affected their probability of infection (Rowley and Alford 2013) and this related to the thermal

341 sensitivity of the B. dendrobatidis (Daskin et al. 2011; Greenspan et al. 2017c). Exposure to the

342 B. dendrobatidis changed host behavior, reducing escape capacity and foraging in different

343 tadpole species (Han et al. 2011; Venesky et al. 2009).

Another prominent behaviour of anurans, and an obvious subject of such research with profound consequences for ecology and life history, is reproductive calling. Seasonal patterns of calling resulted from interactions between infection by $B$. dendrobatidis and body condition in the Common mist frog Litoria rheocola (Roznik et al. 2015). Similarly, Japanese tree frogs Dryophytes [Hyla] japonicas called more rapidly and for longer when infected with the $B$. dendrobatidis (An and Waldman 2016). Contrary to these results, calling was reduced in Brazilian subtropical treefrog (Hypsiboas prasinus) infected with helminth parasites and this was exacerbated in smaller individuals (Madelaire et al. 2013). Conversely, Grey Treefrog $(H$. versicolour) calling characteristics remained unchanged, though males with greater parasite loads achieved more amplexus (Hausfater et al. 1990). In spadefoot toads (Scaphiopus couchii), males parasitised by a monogenean worm (Pseudodiplorchis americanus) had more attractive calls to females, thereby skewing female choice (Pfennig and Tinsley 2002). While calling duration in Cururu toads (Rhinella icterica) was not affected by nematode lungworms (Rhabdius $s p$.), locomotory performance was reduced and this may have played some role in the capacity of Another model system in the study of the effects of parasites on anuran movement is the infamous invasion of cane toads (Rhinella [Bufo] marina) in Australia (Shine 2010). As is the case with many invasive species, use of 'natural' parasites has been explored for potential

365 Survival and growth rate of metamorph cane toads ( $R$. marina) was reduced, alongside impaired 
locomotory performance and reduced prey intake when infected with Rhabdius

367 pseudospaheracephala) (Kelehear et al. 2009) and toads showed no tendency to avoid areas

368 inhabited by a lungworm, nor demonstrated the capacity to avoid infection (Kelehear et al.

369 2011). However, infection did not affect dispersal behaviour of adult toads (Brown et al. 2016).

370 A bacteria (Ochrobactrum anthropi) was also explored as a causative agent of spinal arthropathy

371 in cane toads (R. marina) (Brown et al. 2007; Shilton et al. 2008), though the effects on toads

372 appear to relate to climate and growth (Bower et al. 2018).

Original theoretical frameworks of disease ecology assumed that parasite burden and effects

375 were directly related to parasite abundance and distribution within the host population, with all

376 individuals having an equal, random chance of infection (Anderson 1978). More recently,

377 emphasis has shifted towards a social network style of analysis (Bull et al. 2012; Godfrey 2013),

378 with evidence that context and interactions between individuals strongly effect parasite

379 transmission and parasite species assemblages. For example, social association in the sleepy

380 lizard (T. rugosa) had a stronger link to parasite sharing and transmission than did common

381 resource use (Bull et al. 2012; Sih et al. 2017). Similarly, tick infestation (Amblyomma

382 sphenodonti) and a blood parasite (Hepatozoon tuatarae) transmitted by the tick in the tuatara

383 (Sphenodon punctatus) was significantly related to social interaction (Godfrey et al. 2010). We

384 suggest that theoretical models and predictions of parasite transfer, and the demographic effects

385 of parasites should be updated in response to these findings.

387 Studies examining how parasites affect the behaviours of reptiles and amphibians are neither 388 complete nor comprehensive in taxonomic coverage. For example, Corethtrellid flies

389 (Corethrella sp.) use frog calls to locate potential hosts (Bernal et al. 2006), yet despite several 390 studies describing the prevalence of parasitism of anuran amphibians by these and Batrachomyia 391 flies (Batrachomyia sp.) (Elkan 1965; Hoskin and McCallum 2007; Kraus 2007), we still do not 392 have a strong understanding of how myiasis (infection with fly larva) influences behaviours of 393 amphibian hosts. Additionally, studies are lacking for entire taxonomic groups; little research has 394 explored the effects of parasites on the behaviour of Gymnophionan amphibians (Caecilians) and 395 surprisingly, Crocodilians. Opportunities certainly exist to improve our understanding of the role 396 of parasites in shaping behaviour, which plays a critical role in ecology. 


\section{5. Physiology}

399 Evidence of the adverse effects of parasites on the physiological condition of reptile and 400 amphibian hosts is mounting (Koprivnikar et al. 2012; Martín et al. 2008; Oppliger et al. 1996;

401 Schall et al. 1982; Van Rooij et al. 2015). Parasites that consume or destroy red blood cells, such 402 as ticks and hemogregarine protozoa, can reduce hemoglobin concentrations and the capacity for 403 blood to deliver oxygen to tissues (Dunlap and Mathies 1993; Martín et al. 2008; Oppliger et al. 404 1996). Trematodes (Ribeiroia sp.) encyst in the developing limb buds of amphibians, causing 405 abnormal cellular growth, leading to limb abnormalities (Johnson et al. 2001; Johnson et al. 406 1999; Stopper et al. 2002) and in garter snakes (Thamnophis sirtalis) trematodes (Alaria sp.) 407 cause extensive muscle damage (Uhrig et al. 2015). The fungal chytrid genus Batrachochytrium 408 damages the permeable skin of amphibians, causing loss of water and electrolyte equilibrium 409 (Voyles et al. 2009).

411 Disruption of physiological processes by parasites can influence individual performance and 412 interactions within and between species. At times, interference with physiological processes 413 causes direct mortality, as in tadpoles of Leopard frogs (L. pipiens) with trematode (Family:

414 Echinostomatidae) infections (Schotthoefer et al. 2003), toads (R. marina) with tick infestations 415 (Lampo and Bayliss 1996), and many frog species infected with the fungus B. dendrobatidis 416 (Berger et al. 1998). Altered physiology from parasitism may also influence other measures of 417 fitness such as body condition. Western fence lizards, (Sceloporus occidentalis) with malaria 418 (Plasmodium mexicanum) exhibited decreased fat storage (Schall 1983), as did desert toads 419 (Scaphiopus couchii) infected with a monogenean blood parasite Pseudodiplorchis americanus, 420 after emergence from hibernation (Tocque 1993). Similarly, tick-infection in cane toads $(R$. 421 marina) reduced their ability to gain weight (Lampo and Bayliss 1996). Decreases in mass or fat 422 deposition could result from allocation of energy to immune defenses, or decreases in aerobic 423 activities such as foraging or defense of foraging territories, as postulated for western fence 424 lizards (Sceloporus occidentalis) with heavy tick (Ixodes pacificus) loads (Dunlap and Mathies 425 1993). 
427 Although comparatively light tick loads (I. pacificus) do not appear to influence the body

428 condition of western fence lizards (S. occidentalis), co-infection with malarial protozoa $(P$.

429 mexicanum) had a negative effect on host condition because both parasites reduced hemoglobin

430 concentrations by different pathways, leading to further physiological costs (Dunlap and Mathies

431 1993).

432

433 The physiological effects of parasites may also increase the risk of host predation. In pacific tree

434 frogs (Hyla regilla) with trematode infections (Ribeiroia sp.), limb abnormalities hindered the

435 mobility necessary for predator avoidance (Goodman and Johnson 2011a; b; Johnson et al.

436 1999). Similarly, running stamina was reduced in malaria-infected (P. mexicanum) western fence

437 lizards (S. occidentalis) (Schall et al. 1982). In common lizards (Z. vivipara) infected with

438 hemogregarines, (Haemogregarina sp.) locomotor speeds were lowered (Oppliger et al. 1996),

439 and rates of tail regeneration (an important mechanism of predator escape) were slower

440 (Oppliger and Clobert 1997). Another pathway by which parasites may alter host physiology is

441 by reducing host thermal tolerance, as with spotted tree frogs (Litoria spenceri) infected by the

442 fungus $B$. dendrobatidis (Greenspan et al. 2017a) and newts (Notophthalmus viridescensa)

443 infected with mesomycetozoan parasite (described as an Ichthyophonus-like organism) (Sherman

444 2008), a reminder that anthropogenic environmental factors, such as climate variability

445 associated with global change and environmental contaminants, can exacerbate the harmful

446 physiological effects of infection (Chatfield et al. 2013; Marcogliese et al. 2009).

448 Altered host physiology by parasites can also influence reproductive processes. Malaria-infected

449 (P. mexicanum) lizards (S. occidentalis) had reduced clutch and testis sizes (Schall 1983). In

450 European green lizards (Lacerta viridis) with high tick (Ixodes ricinus) burdens, females had

451 more saturated chest coloration, which may have indicated avoidance of highly aerobic

452 interactions such as courtship and mating (Václav et al. 2007). European green lizards (Lacerta

453 viridis) parasitized by ticks (I. ricinus) (Václav et al. 2007) and wall lizards (Podarcis muralis)

454 infected with hemogregarine blood protozoa (family Haemogregorinidae) (Martín et al. 2008)

455 had less-saturated throat coloration, indicating that resources were allocated to other

456 physiological processes such as immunity, at the expense of processes associated with breeding

457 coloration that help to attract females (Václav et al. 2007)..

This article is protected by copyright. All rights reserved 
459 While there are a number of examples where infection with a parasite led to decreased 460 reproductive effort, there are cases where infection led to increased reproductive effort. In frogs 461 infected with fungus (B. dendrobatidis), male leopard frogs (R. pipiens) had increased testis size, 462 male southern corroboree frogs (Pseudophryne corroboree) and alpine tree frogs (Litoria 463 verreauxii alpina) had increased sperm production (Brannelly et al. 2016; Chatfield et al. 2013), 464 and female alpine tree frogs (L. v. alpina) had increased gonad size as well as an increased 465 number of developed eggs inside the ovaries (Brannelly et al 2016). Further, the energetic costs 466 of reproduction can lead to a situation in which immune function is decreased in a trade-off 467 favouring reproductive processes. Wild female tree lizards (Urosaurus ornatus) in Arizona had 468 reduced immune function during egg production (vitellogenesis) (French and Moore 2008).

469 Controlled experiments demonstrated that this decrease in immune function only occurs when 470 food resources become limited, suggesting that this is a facultative response (French and Moore 471 2008). This trade-off between reproduction and immune response could conceivably result in 472 increased susceptibility to disease.

474 Parasites can also influence the phenotypes of host offspring through physiological tradeoffs 475 (Poulin and Thomas 2008). Common lizards (Z. vivipara) in poor condition from blood parasite 476 infection (family Haemogregarinidae), allocated a higher proportion of resources to offspring 477 locomotory performance than to other aspects of offspring performance, which increased sprint 478 speed and survival rates of female offspring, presumably serving to preadapt female offspring to 479 challenging environmental conditions (Sorci et al. 1996). In addition, the physiological costs of 480 blood parasites may reduce the competitive ability between species. On a Caribbean island with 481 malaria-susceptible Anole lizards, Anolis gingivinus out-competed Anolis wattsi in the absence 482 of infection by Plasmodium azurophilum; therefore the two species co-occur only in areas with 483 malaria (Schall 1992). In some cases, an individual's own physiological processes may cause 484 immunosuppression, leaving them at risk of parasite invasion. Experimentally elevated levels of 485 the hormone testosterone correlated with increased tick (Ixodes ricinus) load in free living male 486 sand lizards (Lacerta agilis) and large psammodromus lizards (Psammodromus algirus) (Olsson 487 et al. 2000; Salvador et al. 1996). The ticks negatively reduced the relative number of white 488 blood cells and hemoglobin and increased hematocrit of P. algirus, and males with 
experimentally elevated testosterone levels experienced higher mortality. Although there is

490 debate on this topic, there is evidence showing that increased testosterone causes

491 immunosupporession (Foo et al. 2017). This provides support for the immunocompetence-

492 handicap hypothesis (ICHH), as testosterone levels are correlated with increased sexual signals

493 (such as colour) and males demonstrate their true fitness by surviving the detrimental effect of

494 increased parasite load (Olsson et al. 2000). This hypothesis may explain why brightly coloured

495 male Aruban Whip tail lizards (Cnemidophorus arubensis) were more likely to be infected with a

496 hemogregarine blood protozoa (family Haemogregorinidae) than dull males of the same body

497 size (Schall 1986). Similarly, Anole lizards (Anolis sagrei) that tolerated infection by

498 Plasmodium parasites displayed better body condition than uninfected individuals and were not

499 negatively affected in mortality, stamina and immunocompetence (Bonneaud et al. 2017).

6. Genomics

502 At a population level, host genetic diversity can influence parasite load, and consequently

503 disease dynamics. Studies across taxa have demonstrated that host genetic variation dictates

504 parasite susceptibility; populations with greater genetic diversity tend to respond more variably

505 to infection, while homogenous populations suffer from the 'monoculture effect,' making them

506 more susceptible to disease (Altermatt and Ebert 2008; Coltman et al. 1999; King and Lively

507 2012; O'Brien et al. 1985; Thorne and Williams 1988; Whiteman et al. 2006). This increased

508 parasite susceptibility with a loss of genetic diversity has been seen in the Italian agile frog

509 (Rana latastei) exposed to ranavirus, where decreased survival correlated with population

510 genetic depletion (Pearman and Garner 2005). Disease outbreaks in inbred and bottlenecked

511 populations may be particularly severe due to a loss of adaptive capacity, the potential loss of

512 alleles conferring resistance, and accumulation of those that are deleterious.

514 In the evolutionary arms race between pathogen and host, one component of the genome

515 involved in rapid adaptation to pathogen-mediated selection is the highly polymorphic Major

516 Histocompatibility Complex (MHC). Depending on the disease context, MHC allele distributions

517 may be maintained by negative frequency-dependent selection, heterozygote advantage, and/or

518 fluctuating selection (Borghans et al. 2004; Doherty and Zinkernagel 1975; Hedrick 2002;

519 Spurgin and Richardson 2010). A recent hypothesis is that diversity of MHC and/or other 
520 immune genes may have facilitated the evolution of group living in members of the Egerniinae

521 lizards, but this remains untested (Bull et al. 2017). The relationship between MHC

522 polymorphism and parasite load is unclear in reptiles. In the Ornate dragon (Ctenophorus

523 ornatus), tick load was positively correlated with MHC diversity in undisturbed habitats, though

524 no relationship was evident in disturbed areas (Radwan et al. 2014).

526 In amphibians, both diversifying and directional selection contribute to MHC diversity (Savage

527 and Zamudio 2011; Teacher et al. 2009; Wang et al. 2017). Among populations of Black-spotted

528 pond frogs (Pelophylax nigromaculatus), MHC class Ia genetic diversity was positively

529 correlated with viral abundance and richness. Moreover, there were significant correlations

530 between MHC functional supertypes and either Frog virus 3 or Ambystoma tigrinum virus,

531 suggesting that these supertypes may have conferred resistance (Wang et al. 2017). By

532 comparing ranavirus-infected and uninfected populations of the European Common Frog (Rana

533 temporaria), directional selection for specific MHC supertypes in diseased populations was

534 demonstrated (Teacher et al. 2009). Similarly, both MHC class IIb heterozygosity and presence

535 of the specific Q allele were associated with increased survival in Lowland leopard frogs

536 (Lithobates yavapaiensis) experimentally infected with fungus (B. dendrobatidis) (Savage and

537 Zamudio 2011). Directional selection for survival-associated alleles was further confirmed in

538 natural populations of L. yavapaiensis, suggesting evolution of tolerance to B. dendrobatidis in

539 this species (Savage and Zamudio 2016). Finally, while the relationship between parasite burden

540 and MHC alleles is unclear in the critically endangered corroboree frog (Pseudophryne

541 corroboree), recent evidence demonstrates both high MHC class Ia diversity and signatures of

542 positive selection at the peptide binding region, indicating that this locus may be important in

543 adaptation to disease (Kosch et al. 2017).

545 In addition to adaptation, plasticity in host response to a disease can dictate parasite load.

546 Interpreting host response at the level of gene expression is particularly useful when genomic

547 resources are limiting, as in amphibians, where large genome sizes have precluded assembly in

548 all but three taxa (Hellsten et al. 2010; Session et al. 2016; Sun et al. 2015). Microarray and

549 RNA-sequencing in experimental infection trials was most extensively undertaken in the

550 amphibian chytrid fungus (B. dendrobatidis) system (Ellison et al. 2014a; Ellison et al. 2014b; 
551 Grogan et al. 2018; Rosenblum et al. 2012a; Rosenblum et al. 2012b; Rosenblum et al. 2009).

552 Among susceptible species, infection led to decreased expression of transcripts related to skin

553 integrity — such as those in the keratin and elastin pathways — while resistant species upregulated

554 skin integrity-related transcripts (Ellison et al. 2014b; Rosenblum et al. 2012b; Rosenblum et al.

555 2009). Central American frogs with varied responses to fungal (B. dendrobatidis) infection

556 exhibited species-specific differences in gene expression, with highly susceptible species

557 demonstrating both increased expression of transcripts related to inflammation and suppression

558 of lymphocyte activation and proliferation pathways (Ellison et al. 2014a; Ellison et al. 2014b).

559 Such differences in gene expression not only dictate host infection outcomes, but may also

560 influence parasite evolutionary trajectory. For example, when grown in vivo in a susceptible

561 species versus in culture, the fungus (B. dendrobatidis) simultaneously increased expression of

562 transcripts involved in proteolysis, transmembrane transport, and cilium morphogenesis, and

563 exhibited a shift in expressed genotype frequencies (Ellison et al. 2017). Disentangling the extent

564 to which host genomic and transcriptomic variation may influence rapid evolution in parasite

565 populations holds great promise for refining our understanding of disease dynamics.

\section{Conservation}

568 Parasite infection and disease is often not the sole cause of extinction or even the major contributor to declines in many species of amphibians and reptiles (Gibbon et al. 2000; Lafferty and Gerber 2002). However, when combined with other stressors, such as population

571 fragmentation or invasive species, a parasite can rapidly devastate a population (Gibbon et al.

572 2000; Tompkins et al. 2015). Parasites can affect population viability by causing death, or

573 increasing susceptibility to predators or other stressors, thereby decreasing reproductive capacity

574 and population growth (Cunningham 1996; Lafferty and Gerber 2002). Disease often affects

575 endangered species and those with small populations more dramatically than abundant species

576 (May 1988). One such example is the flattened musk turtle (Sternotherus depressus), a species

577 threatened by habitat change. One population experienced a massive decline (decrease of 50\%)

578 over twelve months, primarily caused by septicemia (Dodd Jr 1988). Compounded further by

579 localised poaching of turtles, the severity and impact of that particular disease outbreak was

580 attributed to a weakened immune function due to environmental stress (Dodd Jr 1988).

581 Septicemia does not seem to cause similar effects in other turtle species or populations, further 
582 suggesting that environmental stressors can exacerbate the effects of disease in threatened 583 species.

585 Disease is a greater threat generally for endangered and rare species; therefore, management 586 tools used for conservation need to incorporate disease and risk thereof into conservation 587 strategy. Some examples of where such considerations are vital are when managing captive 588 assurance colonies, reintroductions and translocations. Understanding disease is an important 589 component of bringing animals into captivity, as well as the implications of releasing them into 590 the wild. In the past, animal releases have caused more harm than good when parasites were 591 relocated with the target species (Cunningham 1996; Deem et al. 2001; Viggers et al. 1993).

592 Most current management practices follow strict guidelines for quarantining animals intended for 593 reintroduction/translocation programs and screen for parasites before release (Cunningham 594 1996). However, continued movement of wildlife for the pet trade and food provides a less 595 regulated, ongoing risk (Gratwicke et al. 2010) Improved biosecurity and disease quarantine 596 protocols increase the success of reintroductions (Germano and Bishop 2009), and reduce 597 movement of parasites between locations because disease can impact the target species as well as 598 sympatric species (Cunningham 1996; Viggers et al. 1993). However, by removing parasites 599 prior to translocation, host-parasite interactions may be disrupted to the detriment of the host 600 (Northover et al. 2018), and more research is needed to understand the risks here.

602 While most parasites that affect reptiles and amphibians do not result in mass mortality in wild 603 populations, stressful conditions in captivity can cause high morbidity and mortality that would 604 otherwise have minimal impact in the wild (Pessier 2008). One such disease is mucormycosis, 605 which is caused by the fungus Mucor amphibiorum. Mucormycosis is rare in wild frog 606 populations (Berger et al. 1997; Speare et al. 1997), but has on occasion caused $80 \%$ mortality in 607 captive colonies in Australia and Germany (Creeper et al. 1998). Another example is boid 608 inclusion body disease, which is likely caused by a retrovirus and causes central nervous system 609 abnormalities and death in affected captive boid snakes (Chang and Jacobson 2010). While boid 610 inclusion body disease is a global issue, it has only been reported in captivity (Chang and 611 Jacobson 2010; Hetzel et al. 2013). A third example is the bacteria Pseudomonas sp, which 612 caused an outbreak of necrotic dermatitis in a captive colony of the critically endangered western 
613 swamp turtle (Pseudemydura umbrina). This caused high mortality in the captive population

614 (Ladyman et al. 1998), but similar infections have not been detected in wild populations.

615 Diseases such as those described above can delay or prevent reintroduction attempts, as well as

616 reducing the number of precious individuals in captive insurance populations. Simply due to

617 spatial constraints, animals brought into captivity are often maintained at higher than natural

618 population densities, potentially resulting in stressful conditions that may lower the immune

619 capacity to respond to infection. Captive disease outbreaks might therefore be minimized by

620 developing a better understanding of how these are mediated by captive husbandry (e.g.

621 nutrition, housing) of reptiles and amphibians (Pessier 2008).

622

623 The impacts of the disease chytridiomycosis on amphibians has been well-studied and reviewed

624 (Bower et al. 2017a; Scheele et al. 2014; Woodhams et al. 2011), and mitigating risk of the

625 spread of this pathogen has been incorporated into policy governing the management of

626 threatened and declining amphibian species (Commonwealth of Australia 2016). However, the

627 same research and management effort has not been undertaken for other diseases. Where

628 diseases do not directly cause species extinction, populations can still be negatively impacted by

629 parasites, particularly in small populations. For example, ranavirus is widespread in amphibian

630 and reptile species globally, and while it can cause mass declines, it often does not. However,

631 only after a long-term study exploring many different ranavirus-positive and ranavirus-negative

632 populations is it clear that ranavirus has an overall negative effect on population growth over

633 time (Teacher et al. 2010).

634

635 The extent to which parasites can act as a threatening process is unclear in many cases. Long

636 term population level effects of Fibropapillomatosis are unknown in most regions, but Hawaiian

637 green turtle populations have recovered from initial declines despite disease presence

638 (Chaloupka and Balazs 2005; Jones et al. 2016). While myxosporea and sparganosis cause

639 disease in amphibians, and occur in many locations around the globe, prevalence in amphibian

640 communities and impact of disease on populations is essentially unknown (Berger et al. 2009).

641 Most diseases described in reptiles and amphibians are reported as case studies, often without

642 information of disease prevalence or population impact.

643

This article is protected by copyright. All rights reserved 
644 A greater understanding of basic ecology such as population level dynamics and impacts of

645 disease is required for a more thoroughly informed effort in undertaking conservation of

646 declining reptiles and amphibians. Presently, there is relatively little research being conducted to

647 address such questions for a majority of known parasites. Furthermore, many parasites regulate

648 host populations without necessarily causing conservation concern. This may manifest through

649 effects on coexistence, competition, predation and herbivory that help maintain diversity in the

650 system through a complex set of interactions (Hatcher et al. 2012). Disease is often not the

651 ultimate cause of extinction; therefore, minimising other stressors, such as habitat fragmentation

652 and pollution, will increase the resilience of populations and their ability to tolerate diseases in

653 the future. However, there is also a clear need to understand how parasites and their hosts

654 interact with each other and the environment if we are to be best prepared to manage the

655 inevitable consequences of ongoing anthropogenic activity. Threatening factors are not limited to

656 hosts, parasites themselves may be up to ten times more vulnerable than host baseline extinction

657 rate (Colwell et al. 2012). Given the infancy of our understanding of parasite ecology from

658 species diversity through to functional roles, and the lack of current capacity for parasite

659 conservation, these impacts are difficult to predict (Cizauskas et al. 2017). The increasing

660 appreciation of a global decline in biodiversity, particularly of amphibians and reptiles (Gibbon

661 et al. 2000) suggests that future research is certain to further unravel mechanisms that allow us to

662 understand the role played by parasites in ecology and evolution.

663

664 Acknowledgements

665 We thank Dr. Astrid Vachette for generously donating her time and expertise to translate the

666 abstract to French, Dale Burzacott and Wesley Neely for providing photographs and the

667 Winifred Violet Scott Charitable Trust for providing financial support.

668

669

670

671

672

673

674

\section{Literature Cited}

Allender M. C., Raudabaugh D. B., Gleason F. H. \& Miller A. N. (2015) The natural history, ecology, and epidemiology of Ophidiomyces ophiodiicola and its potential impact on free-ranging snake populations. Fungal Ecol. 17, 187-96.

Altermatt F. \& Ebert D. (2008) Genetic diversity of Daphnia magna populations enhances resistance to parasites. Ecol Lett 11, 918-28.

This article is protected by copyright. All rights reserved 
An D. \& Waldman B. (2016) Enhanced call effort in Japanese tree frogs infected by amphibian chytrid fungus. Biol Lett 12, 20160018.

Anderson R. (1978) The regulation of host population growth by parasitic species. Parasitology 76, 119-57.

Ariel E. (2011) Viruses in reptiles. Vet Res 42, 100.

Aubret F., Tort M., Michniewicz R. J., Blanvillain G. \& Coulon A. (2014) Cooperate or compete? Influence of sex and body size on sheltering behaviour in the wall lizard, Podarcis muralis. Behaviour 151, 1903-20.

Berger L., Skerratt L. F., Zhu X.-Q., Young S. \& Speare R. (2009) Severe sparganosis in Australian tree frogs. $J$ Wildl Dis 45, 921-9.

Berger L., Speare R., Daszak P., Green D. E., Cunningham A. A., Goggin C. L., Slocombe R., Ragan M. A., Hyatt A. D., McDonald K. R., Hines H. B., Lips K. R., Marantelli G. \& Parkes H. (1998) Chytridiomycosis causes amphibian mortality associated with population declines in the rain forests of Australia and Central America. Proc Natl Acad Sci USA 95, 9031-6.

Berger L., Speare R. \& Humphrey J. (1997) Mucormycosis in a free-ranging green tree frog from Australia. J Wildl Dis 33, 903-7.

Bernal X. E., Page R. A., Rand A. S. \& Ryan M. J. (2007) Cues for eavesdroppers: do frog calls indicate prey density and quality? Am. Nat. 169, 409-15.

Bernal X. E. \& Pinto C. M. (2016) Sexual differences in prevalence of a new species of trypanosome infecting túngara frogs. International Journal for Parasitology: Parasites and Wildlife 5, 40-7.

Bernal X. E., Rand A. S. \& Ryan M. J. (2006) Acoustic preferences and localization performance of blood-sucking flies (Corethrella Coquillett) to túngara frog calls. Behav Ecol 17, 709-15.

Biaggini M., Berti R. \& Corti C. (2009) Different habitats, different pressures? Analysis of escape behaviour and ectoparasite load in Podarcis sicula (Lacertidae) populations in different agricultural habitats. Amphib-Reptilia 30, 453-61.

Bonneaud C., Sepil I., Wilfert L. \& Calsbeek R. (2017) Plasmodium infections in natural populations of Anolis sagrei reflect tolerance rather than susceptibility. Integr Comp Biol 57, 352-61. 
Borghans J. A., Beltman J. B. \& De Boer R. J. (2004) MHC polymorphism under host-pathogen coevolution. Immunogenetics 55, 732-9.

Bouma M. J., Smallridge C. J., Bull C. M. \& Komdeur J. (2007) Susceptibility to infection by a haemogregarine parasite and the impact of infection in the Australian sleepy lizard Tiliqua rugosa. Parasitol Res 100, 949-54.

Bower D., Mengersen K., Alford R. \& Schwarzkopf L. (2017a) Using a Bayesian network to clarify areas requiring research in a host-pathogen system. Conserv Biol 31, 1373-82.

Bower D. S., Lips K. R., Schwarzkopf L., Georges A. \& Clulow S. (2017b) Amphibians on the brink: Preemptive policies can protect amphibians from devastating fungal diseases. Science 257, 8-9.

Bower D. S., Yasumiba K., Trumbo D. R., Alford R. A. \& Schwarzkopf L. (2018) Spinal arthritis in cane toads across the Australian landscape. Sci. Rep. 8, 12458.

Brannelly L. A., Webb R., Skerratt L. F. \& Berger L. (2016) Amphibians with infectious disease increase their reproductive effort: evidence for the terminal investment hypothesis. Open biology 6, 150251.

Brown G., Shilton C. \& Shine R. (2006) Do parasites matter? Assessing the fitness consequences of haemogregarine infection in snakes. Can J Zool 84, 668-76.

Brown G. P., Kelehear C., Pizzatto L. \& Shine R. (2016) The impact of lungworm parasites on rates of dispersal of their anuran host, the invasive cane toad. Biol Invasions 18, 103-14.

Brown G. P., Shilton C., Phillips B. L. \& Shine R. (2007) Invasion, stress, and spinal arthritis in cane toads. Proceedings of the National Academy of Sciences 104, 17698-700.

Bull C., Godfrey S. \& Gordon D. (2012) Social networks and the spread of Salmonella in a sleepy lizard population. Mol Ecol 21, 4386-92.

Bull C. M. \& Burzacott D. A. (2006) The influence of parasites on the retention of long-term partnerships in the Australian sleepy lizard, Tiliqua rugosa. Oecologia 146, 675-80.

Bull C. M., Gardner M. G., Sih A., Spiegel O., Godfrey S. S. \& Leu S. T. (2017) Why is social behavior rare in reptiles? Lessons from sleepy lizards. Adv Study Behav 49, 1-26.

Byrd A. L. \& Segre J. A. (2016) Adapting Koch's postulates. Science 351, 224-6.

Campião K. M., Delatorre M., Rodrigues R. B., Da Silva R. J. \& Ferreira V. L. (2012) The effect of local environmental variables on the helminth parasite communities of the pointedbelly 
frog Leptodactylus podicipinus from ponds in the Pantanal wetlands. J Parasitol 98, 22935.

738 Carbayo J., MARTIN J. \& Civantos E. (2018) Habitat type influences parasite load in Algerian Psammodromus lizards (Psammodromus algirus). Can J Zool Early online.

Chaloupka M. \& Balazs G. (2005) Modelling the effect of fibropapilloma disease on the somatic growth dynamics of Hawaiian green sea turtles. Mar. Biol. 147, 1251-60.

742 Chambouvet A., Gower D. J., Jirků M., Yabsley M. J., Davis A. K., Leonard G., Maguire F., Doherty-Bone T. M., Bittencourt-Silva G. B. \& Wilkinson M. (2015) Cryptic infection of a broad taxonomic and geographic diversity of tadpoles by Perkinsea protists. Proceedings of the National Academy of Sciences 112, E4743-E51.

Chang L.-W. \& Jacobson E. R. (2010) Inclusion body disease, a worldwide infectious disease of boid snakes: a review. J Exot Pet Med 19, 216-25.

Chatfield M. W., Brannelly L. A., Robak M. J., Freeborn L., Lailvaux S. P. \& Richards-Zawacki C. L. (2013) Fitness consequences of infection by Batrachochytrium dendrobatidis in northern leopard frogs (Lithobates pipiens). EcoHealth 10, 90-8.

Christin M. S., Gendron A. D., Brousseau P., Ménard L., Marcogliese D. J., Cyr D., Ruby S. \& Fournier M. (2003) Effects of agricultural pesticides on the immune system of Rana pipiens and on its resistance to parasitic infection. Environ Toxicol Chem 22, 1127-33.

Cizauskas C. A., Carlson C. J., Burgio K. R., Clements C. F., Dougherty E. R., Harris N. C. \& Phillips A. J. (2017) Parasite vulnerability to climate change: An evidence-based functional trait approach. Royal Society open science 4, 160535.

Collins J. P. \& Storfer A. (2003) Global amphibian declines: sorting the hypotheses. Divers Distrib 9, 89-98.

Coltman D. W., Pilkington J. G. \& Smith J. A. (1999) Parasite-mediated selection against inbred soay sheep in a free-living island population. Evolution 53, 1259-67.

Colwell R. K., Dunn R. R. \& Harris N. C. (2012) Coextinction and persistence of dependent species in a changing world. Annu. Rev. Ecol. Evol. Syst. 43, 183-203.

Commonwealth of Australia. (2016) Draft Threat abatement plan for infection of amphibians with chytrid fungus resulting in chytridiomycosis, http://www.environment.gov.au/biodiversity/threatened/publications/tap/infectionamphibians-chytrid-fungus-resulting-chytridiomycosis. 
Cooper E. L., Wright R. K., Klempau A. E. \& Smith C. T. (1992) Hibernation alters the frog's immune system. Cryobiology 29, 616-31.

Creeper J., Main D., Berger L., Huntress S. \& Boardman W. (1998) An outbreak of mucormycosis in slender tree frogs (Litoria adelensis) and white-lipped tree frogs (Litoria infrafrenata). Aust Vet J 76, 761-2.

772 Crofton H.(1971) A model of host-parasite relationships. Parasitology 63, 343-64.

773 Cunningham A. A. (1996) Disease risks of wildlife translocations. Conserv Biol 10, 349-53.

774 Czech B., Krausman P. R. \& Borkhataria R. (1998) Social construction, political power, and the 775 allocation of benefits to endangered species. Conserv Biol 12, 1103-12.

Damas-Moreira I., Harris D. J., Rosado D., Tavares I., Maia J. P., Salvi D. \& Perera A. (2014) Consequences of haemogregarine infection on the escape distance in the lacertid lizard, Podarcis vaucheri. Acta Herpetol 9, 119-23.

Day R. D., Segars A. L., Arendt M. D., Lee A. M. \& Peden-Adams M. M. (2007) Relationship of blood mercury levels to health parameters in the loggerhead sea turtle (Caretta caretta). Environ Health Perspect 115, 1421.

Deem S. L. Karesh W. B. \& Weisman W. (2001) Putting theory into practice: wildlife health in conservation. Conserv Biol 15, 1224-33.

Di Rosa I., Simoncelli F., Fagotti A. \& Pascolini R. (2007) Ecology: The proximate cause of frog declines? Nature 447, E4.

Dodd Jr C. K. (1988) Disease and population declines in the flattened musk turtle Sternotherus depressus. Am Midl Nat 119, 394-401.

Doherty P. C. \& Zinkernagel R. M. (1975) Enhanced immunological surveillance in mice heterozygous at the H-2 gene complex. Nature 256, 50.

Dunlap K. D. \& Mathies T. (1993) Effects of nymphal ticks and their interaction with malaria on the physiology of male fence lizards. Copeia 1993, 1045-8. 
Eiras J. C. (2005) An overview on the myxosporean parasites in amphibians and reptiles. Acta Parasitol 50, 267-75.

Elkan E. (1965) Myiasis in Australian frogs. Ann Trop Med Parasitol 59, 51-4.

800 Ellison A. R., DiRenzo G. V., McDonald C. A., Lips K. R. \& Zamudio K. R. (2017) First in vivo Batrachochytrium dendrobatidis transcriptomes reveal mechanisms of host exploitation, host-specific gene expression, and expressed genotype shifts. G3: Genes, Genomes, Genetics 7, 269-78.

Ellison A. R., Savage A. E., DiRenzo G. V., Langhammer P., Lips K. R. \& Zamudio K. R. (2014a) Fighting a losing battle: vigorous immune response countered by pathogen suppression of host defenses in the chytridiomycosis-susceptible frog Atelopus zeteki. G3: Genes, Genomes, Genetics 4, 1275-89.

Ellison A. R., Tunstall T., DiRenzo G. V., Hughey M. C., Rebollar E. A., Belden L. K., Harris R. N., Ibáñez R., Lips K. R. \& Zamudio K. R. (2014b) More than skin deep: functional genomic basis for resistance to amphibian chytridiomycosis. Genome Biol. Evol. 7, 28698.

Ferguson L. V. \& Smith T. G. (2012) Reciprocal trophic interactions and transmission of blood parasites between mosquitoes and frogs. Insects 3, 410-23.

Field D. J., Gauthier J. A., King B. L., Pisani D., Lyson T. R. \& Peterson K. J. (2014) Toward consilience in reptile phylogeny: miRNAs support an archosaur, not lepidosaur, affinity for turtles. Evol Dev 16, 189-96.

Finnerty P. B., Shine R. \& Brown G. P. (2018) The costs of parasite infection: Effects of removing lungworms on performance, growth and survival of free-ranging cane toads. Funct Ecol 32, 402-15.

Fisher M. C., Henk D. A., Briggs C. J., Brownstein J. S., Madoff L. C., McCraw S. L. \& Gurr S. J. (2012) Emerging fungal threats to animal, plant and ecosystem health. Nature 484, 186.

Foo Y. Z., Nakagawa S., Rhodes G. \& Simmons L. W. (2017) The effects of sex hormones on immune function: a meta-analysis. Biological Reviews 92, 551-71.

French S. S. \& Moore M. C. (2008) Immune function varies with reproductive stage and context in female and male tree lizards, Urosaurus ornatus. Gen Comp Endocrinol 155, 148-56. 
827 Germano J. M. \& Bishop P. J. (2009) Suitability of amphibians and reptiles for translocation. $828 \quad$ Conserv Biol 23, 7-15.

829 Gervasi S. S. \& Foufopoulos J. (2008) Costs of plasticity: responses to desiccation decrease 830 post-metamorphic immune function in a pond-breeding amphibian. Funct Ecol 22, 100-8.

831 Gibbon J. W., Scott D. E., Ryan T. J., Buhlmann K. A., Tuberville T. D., Metts B. S., Greene J.

832 L., Mills T., Leiden Y. \& Poppy S. (2000) The Global Decline of Reptiles, Déjà Vu Amphibians: Reptile species are declining on a global scale. Six significant threats to reptile populations are habitat loss and degradation, introduced invasive species, environmental pollution, disease, unsustainable use, and global climate change. Bioscience 50, 653-66.

Giery S. T. \& Ostfeld R. S. (2007) The role of lizards in the ecology of Lyme disease in two endemic zones of the northeastern United States. J Parasitol 93, 511-7.

Goater C. \& Ward P. (1992) Negative effects of Rhabdias bufonis (Nematoda) on the growth and survival of toads (Bufo bufo). Oecologia 89, 161-5.

Godfrey S. S. (2013) Networks and the ecology of parasite transmission: a framework for wildlife parasitology. International Journal for Parasitology: Parasites and Wildlife 2, $235-45$.

Godfrey S. S., Bull C. M., Murray K. \& Gardner M. G. (2006) Transmission mode and distribution of parasites among groups of the social lizard Egernia stokesii. Parasitol Res 99, 223-30.

Godfrey S. S. \& Gardner M. G. (2017) Lizards, ticks and contributions to Australian parasitology: C. Michael Bull (1947-2016). International Journal for Parasitology: Parasites and Wildlife 6, 295-8.

Godfrey S. S., Moore J. A., Nelson N. J. \& Bull C. M. (2010) Social network structure and parasite infection patterns in a territorial reptile, the tuatara (Sphenodon punctatus). Int $J$ Parasitol 40, 1575-85.

Godínez-Álvarez H. (2004) Pollination and seed dispersal by lizards: a review. Rev Chil Hist Nat 77, 569-77.

Goodman B. A. \& Johnson P. T. (2011a) Disease and the extended phenotype: parasites control host performance and survival through induced changes in body plan. PLOS ONE $\mathbf{6}$, e20193. 
Goodman B. A. \& Johnson P. T. (2011b) Ecomorphology and disease: cryptic effects of parasitism on host habitat use, thermoregulation, and predator avoidance. Ecology 92, 542-8.

Graham T., Saumure R. \& Ericson B. (1997) Map turtle winter leech loads. The Journal of parasitology 83, 1185-6.

Gratwicke B., Evans M. J., Jenkins P. T., Kusrini M. D., Moore R. D., Sevin J. \& Wildt D. E. (2010) Is the international frog legs trade a potential vector for deadly amphibian pathogens? Front Ecol Environ 8, 438-42.

Gray M. J., Miller D. L. \& Hoverman J. T. (2009) Ecology and pathology of amphibian ranaviruses. Dis Aquat Org 87, 243-66.

Greenspan S. E., Bower D. S., Roznik E. A., Pike D. A., Marantelli G., Alford R. A., Schwarzkopf L. \& Scheffers B. R. (2017a) Infection increases vulnerability to climate change via effects on host thermal tolerance. Sci. Rep. 7, 9349.

Greenspan S. E., Bower D. S., Webb R. J., Berger L., Rudd D., Schwarzkopf L. \& Alford R. A. (2017b) White blood cell profiles in amphibians help to explain disease susceptibility following temperature shifts. Dev Comp Immunol 77, 280-6.

Greenspan S. E., Bower D. S., Webb R. J., Roznik E. A., Stevenson L. A., Berger L., Marantelli G., Pike D. A., Schwarzkopf L. \& Alford R. A. (2017c) Realistic heat pulses protect frogs from disease under simulated rainforest frog thermal regimes. Funct Ecol 2017, 1-17.

Grillitsch B. \& Schiesari L. (2010) The Ecotoxicology of Metals in Reptiles. In: Ecotoxicology of amphibians and reptiles (eds D. W. Sparling, G. Linder, C. A. Bishop and S. Krest). CRCPress, Second Edition. Boca Raton: CRC Press 337-448.

Grogan L. F., Cashins S. D., Skerratt L. F., Berger L., McFadden M. S., Harlow P., Hunter D. A., Scheele B. C. \& Mulvenna J. (2018) Evolution of resistance to chytridiomycosis is associated with a robust early immune response. Mol Ecol 27, 919-34.

Gyawali P., Khanal S. \& Shrestha B. (2013) Intestinal helminth fauna in sleepy lizard (Tiliqua rugosa) in Australia. International Journal of Veterinary Science 2, 17-20.

Han B. A., Searle C. L. \& Blaustein A. R. (2011) Effects of an infectious fungus, Batrachochytrium dendrobatidis, on amphibian predator-prey interactions. PLoS ONE 6 , e16675. 
Hartigan A., Fiala I., Dyková I., Jirků M., Okimoto B., Rose K., Phalen D. N. \& Šlapeta J. (2011) A suspected parasite spill-back of two novel Myxidium spp.(Myxosporea) causing disease in Australian endemic frogs found in the invasive cane toad. PLoS ONE 6, e18871.

Hartigan A., Phalen D. N. \& Šlapeta J. (2010) Museum material reveals a frog parasite emergence after the invasion of the cane toad in Australia. Parasites \& vectors 3, 50.

Hatcher M. J., Dick J. T. \& Dunn A. M. (2012) Diverse effects of parasites in ecosystems: linking interdependent processes. Front Ecol Environ 10, 186-94.

Hausfater G., Gerhardt H. C. \& Klump G. M. (1990) Parasites and mate choice in gray treefrogs, Hyla versicolor. Am Zool 30, 299-312.

Hecnar S. J. (2009) Human bias and the biodiversity knowledge base: An examination of the published literature on vertebrates. Biodiversity 10, 18-24.

Hedrick P. W. (2002) Pathogen resistance and genetic variation at MHC loci. Evolution 56, 1902-8.

Hellsten U., Harland R. M., Gilchrist M. J., Hendrix D., Jurka J., Kapitonov V., Ovcharenko I., Putnam N. H., Shu S. \& Taher L. (2010) The genome of the Western clawed frog Xenopus tropicalis. Science 328, 633-6.

Hetzel U., Sironen T., Laurinmäki P., Liljeroos L., Patjas A., Henttonen H., Vaheri A., Artelt A., Kipar A. \& Butcher S. J. (2013) Isolation, identification, and characterization of novel arenaviruses, the etiological agents of boid inclusion body disease. J. Virol. 87, 10918-35.

Hoskin C. J. \& McCallum H. (2007) Phylogeography of the parasitic fly Batrachomyia in the Wet Tropics of north-east Australia, and susceptibility of host frog lineages in a mosaic contact zone. Biol J Linn Soc 92, 593-603.

Huggins L. G., Michaels C. J., Cruickshank S. M., Preziosi R. F. \& Else K. J. (2017) A novel copro-diagnostic molecular method for qualitative detection and identification of parasitic nematodes in amphibians and reptiles. PLOS ONE 12, e0185151.

Hussein M., Badir N., El Ridi R. \& El Deeb S. (1979) Effect of seasonal variation on immune system of the lizard, Scincus scincus. Journal of Experimental Zoology Part A: Ecological Genetics and Physiology 209, 91-6.

Innis C., Nyaoke A. C., Williams III C. R., Dunnigan B., Merigo C., Woodward D. L., Weber E. S. \& Frasca Jr S. (2009) Pathologic and parasitologic findings of cold-stunned Kemp's 
ridley sea turtles (Lepidochelys kempii) stranded on Cape Cod, Massachusetts, 20012006. J Wildl Dis 45, 594-610.

921 Iwai N. \& Kagaya T. (2007) Positive indirect effect of tadpoles on a detritivore through nutrient 922 regeneration. Oecologia 152, 685-94.

923 Jani A. J. \& Briggs C. J. (2014) The pathogen Batrachochytrium dendrobatidis disturbs the frog skin microbiome during a natural epidemic and experimental infection. Proceedings of the National Academy of Sciences 111, E5049-E58.

926 Johnson P. T., Lunde K. B., Haight R. W., Bowerman J. \& Blaustein A. R. (2001) Ribeiroia ondatrae (Trematoda: Digenea) infection induces severe limb malformations in western toads (Bufo boreas). Can J Zool 79, 370-9.

929 Johnson P. T., Lunde K. B., Ritchie E. G. \& Launer A. E. (1999) The effect of trematode infection on amphibian limb development and survivorship. Science 284, 802-4.

Kelehear C., Webb J. K., Hagman M. \& Shine R. (2011) Interactions between infective helminth larvae and their anuran hosts. Herpetologica 67, 378-85.

Jones K., Ariel E., Burgess G. \& Read M. (2016) A review of fibropapillomatosis in green turtles

Kelehear C., Webb J. \& Shine R. (2009) Rhabdias pseudosphaerocephala infection in Bufo (Chelonia mydas). The Veterinary Journal 212, 48-57. marinus: lung nematodes reduce viability of metamorph cane toads. Parasitology 136, 919-27.

944 Klein S. L. (2003) Parasite manipulation of the proximate mechanisms that mediate social 945 behavior in vertebrates. Physiol Behav 79, 441-9.

946 Koprivnikar J., Marcogliese D. J., Rohr J. R., Orlofske S. A., Raffel T. R. \& Johnson P. T.

947 (2012) Macroparasite infections of amphibians: what can they tell us? EcoHealth 9, 34294860. 
Koprivnikar J. \& Penalva L. (2015) Lesser of two evils? Foraging choices in response to threats of predation and parasitism. PLOS ONE 10, e0116569.

951 Koprivnikar J., Redfern J. C. \& Mazier H. L. (2014) Variation in anti-parasite behaviour and 952 infection among larval amphibian species. Oecologia 174, 1179-85.

953 Kosch T. A., Eimes J. A., Didinger C., Brannelly L. A., Waldman B., Berger L. \& Skerratt L. F. 954 (2017) Characterization of MHC class IA in the endangered southern corroboree frog. 955 Immunogenetics 69, 165-74.

956 Kraus F. (2007) Fly parasitism in Papuan frogs, with a discussion of ecological factors influencing evolution of life-history differences. J Nat Hist 41, 1863-74.

Ladyman J., Kuchling G., Burford D., Boardman W. \& Raidal S. (1998) Skin disease affecting the conservation of the western swamp tortoise (Pseudemydura umbrina). Aust Vet J 76, $743-5$.

Lafferty K. D. \& Gerber L. R. (2002) Good medicine for conservation biology: the intersection of epidemiology and conservation theory. Conserv Biol 16, 593-604.

Lampo M.\& Bayliss P. (1996) The impact of ticks on Bufo marinus from native habitats.

Parasitology 113, 199-206.

965 Little E. \& Calfee R. (2010) Solar UV radiation and Amphibians. Factors Mitigating Injury. In: Ecotoxicology of amphibians and reptiles (eds D. W. Sparling, G. Linder, C. A. Bishop and S. Krest). CRC Press, Second Edition. Boca Raton: CRC Press 449-471.

Lovich J. E., Ennen J. R., Agha M. \& Gibbons J. W. (2018) Where have all the turtles gone, and why does it matter? Bioscience 68, 771-81.

Lunghi E., Ficetola G. F., Mulargia M., Cogoni R., Veith M., Corti C. \& Manenti R. (2018) Batracobdella leeches, environmental features and Hydromantes salamanders. International Journal for Parasitology: Parasites and Wildlife 7, 48-53.

Madelaire C. B., José da Silva R. \& Ribeiro Gomes F. (2013) Calling behavior and parasite intensity in treefrogs, Hypsiboas prasinus. J Herpetol 47, 450-5.

Madsen T., Ujvari B. \& Olsson M. (2005) Old pythons stay fit; effects of haematozoan infections on life history traits of a large tropical predator. Oecologia 142, 407-12.

Main A. R. \& Bull C. M. (2000) The impact of tick parasites on the behaviour of the lizard Tiliqua rugosa. Oecologia 122, 574-81. 
Maniero G. D. \& Carey C. (1997) Changes in selected aspects of immune function in the leopard frog, Rana pipiens, associated with exposure to cold. Journal of Comparative Physiology B 167, 256-63.

Marcogliese D. J., King K. C., Salo H. M., Fournier M., Brousseau P., Spear P., Champoux L., McLaughlin J. D. \& Boily M. (2009) Combined effects of agricultural activity and parasites on biomarkers in the bullfrog, Rana catasbeiana. Aquat. Toxicol. 91, 126-34.

Marschang R. E. (2011) Viruses infecting reptiles. Viruses 3, 2087-126.

Martín J., Amo L. \& López P. (2008) Parasites and health affect multiple sexual signals in male common wall lizards, Podarcis muralis. Naturwissenschaften 95, 293-300.

Masters N., Alexander S., Jackson B., Sigler L., Chatterton J., Harvey C., Gibson R., Humphrey S., Rawdon T. \& Spence R. (2016) Dermatomycosis caused by Paranannizziopsis australasiensis in five tuatara (Sphenodon punctatus) and a coastal bearded dragon (Pogona barbata) in a zoological collection in New Zealand. N Z Vet J 64, 301-7.

Mauel M. J., Miller D. L., Frazier K. S. \& Hines M. E. (2002) Bacterial pathogens isolated from cultured bullfrogs (Rana castesbeiana). J Vet Diagn Investig 14, 431-3.

May R. M. (1988) Conservation and disease. Conserv Biol 2, 28-30.

May R. M. \& Anderson R. M. (1990) Parasite-host coevolution. Parasitology 100, S89-S101.

McKnight D. T., Schwarzkopf L., Alford R. A., Bower D. S. \& Zenger K. R. (2017) Effects of emerging infectious diseases on host population genetics: a review. Conserv Genet 18, 111.

McManus D. \& Bowles J. (1996) Molecular genetic approaches to parasite identification: their value in diagnostic parasitology and systematics. Int J Parasitol 26, 687-704.

Meredith H., Van Buren C. \& Antwis R. E. (2016) Making amphibian conservation more effective. Conserv Evid 13, 1-6.

Moore J. (1984) Parasites that change the behavior of their host. Sci Am 250, 108-15.

1006

Moretti E. H., Madelaire C. B., Silva R. J., Mendonça M. T. \& Gomes F. R. (2014) The

1007 relationships between parasite intensity, locomotor performance, and body condition in adult toads (Rhinella icterica) from the Wild. J Herpetol 48, 277-83. 
Moretti E. H., Titon Jr B., Madelaire C. B., de Arruda R., Alvarez T. \& Gomes F. R. (2017) Behavioral, physiological and morphological correlates of parasite intensity in the wild Cururu toad (Rhinella icterica). International Journal for Parasitology: Parasites and Wildlife 6, 146-54.

Mugabo M., Perret S., Decencière B., Meylan S. \& Le Galliard J.-F. (2015) Density-dependent immunity and parasitism risk in experimental populations of lizards naturally infested by ixodid ticks. Ecology 96, 450-60.

Northover A., Lymbery A., Wayne A., Godfrey S. \& Thompson R. (2018) The hidden consequences of altering host-parasite relationships during fauna translocations. Biol Conserv 220, 140-8.

O'Brien S. J., Roelke M. E., Marker L., Newman A., Winkler C., Meltzer D., Colly L., Evermann J., Bush M. \& Wildt D. E. (1985) Genetic basis for species vulnerability in the cheetah. Science 227, 1428-34.

O’Dea M. A., Jackson B., Jackson C., Xavier P. \& Warren K. (2016) Discovery and partial genomic characterisation of a novel nidovirus associated with respiratory disease in wild shingleback lizards (Tiliqua rugosa). PLoS ONE 11, e0165209.

Okamura B., Hartigan A. \& Naldoni J. (2018) Extensive uncharted biodiversity: the parasite dimension. In: Integr Comp Biol pp. 1-14, Measuring Biodiversity and Extinction: Present and Past" presented at the annual meeting of the Society for Integrative and Comparative Biology, January 3-7, 2018 at San Francisco, California.

Olsson M., Wapstra E., Madsen T. \& Silverin B. (2000) Testosterone, ticks and travels: a test of the immunocompetence-handicap hypothesis in free-ranging male sand lizards. Proceedings of the Royal Society of London B: Biological Sciences 267, 2339-43.

Oppliger A., Celerier M. \& Clobert J. (1996) Physiological and behaviour changes in common lizards parasitized by haemogregarines. Parasitology 113, 433-8.

Oppliger A. \& Clobert J. (1997) Reduced tail regeneration in the common lizard, Lacerta vivipara, parasitized by blood parasites. Funct Ecol 11, 652-5.

Otero L., Schall J. J., Cruz V., Aaltonen K. \& Acevedo M. (2017) The drivers and consequences of unstable Plasmodium dynamics: A 26-year study of three malaria parasite species infecting a tropical lizard. bioRxiv, 189696. 
Parsons S. K., Bull C. M. \& Gordon D. M. (2010) Low prevalence of Salmonella enterica in Australian wildlife. Environ. Microbiol. Rep. 2, 657-9.

1041 Pasquale V., Baloda S. B., Dumontet S. \& Krovacek K. (1994) An outbreak of Aeromonas

1042 hydrophila infection in turtles (Pseudemis scripta). Appl Environ Microbiol 60, 1678-80.

1043 Pearman P. B. \& Garner T. W. (2005) Susceptibility of Italian agile frog populations to an emerging strain of Ranavirus parallels population genetic diversity. Ecol Lett 8, 401-8.

1045 Pessier A. (2008) Management of disease as a threat to amphibian conservation. Int Zoo Yearb

$1046 \quad \mathbf{4 2}, 30-9$

1047 Pfennig D., Ho S. \& Hoffman E. (1998) Pathogen transmission as a selective force against 1048 cannibalism. Anim Behav 55, 1255-61.

1049 Pfennig D. W., Loeb M. L. \& Collins J. P. (1991) Pathogens as a factor limiting the spread of 1050 cannibalism in tiger salamanders. Oecologia 88, 161-6.

Poulin R. \& Thomas F. (2008) Epigenetic effects of infection on the phenotype of host offspring: parasites reaching across host generations. Oikos 117, 331-5.

Pounds J. A., Bustamante M. R., Coloma L. A., Consuegra J. A., Fogden M. P., Foster P. N., La Marca E., Masters K. L., Merino-Viteri A. \& Puschendorf R. (2006) Widespread amphibian extinctions from epidemic disease driven by global warming. Nature 439, 161.

Pfennig K. S. \& Tinsley R. (2002) Different mate preferences by parasitized and unparasitized females potentially reduces sexual selection. J Evol Biol 15, 399-406.

Ramakrishnan L., Valdivia R. H., McKerrow J. H. \& Falkow S. (1997) Mycobacterium marinum causes both long-term subclinical infection and acute disease in the leopard frog (Rana pipiens). Infect. Immun. 65, 767-73. 
1069 1070

1071

1072

1073

1074

1075

1076

1077

1078

1079

1080

1081

1082

1083

1084

1085

1086

1087

1088

1089

1090

1091

1092

1093

1094

1095

1096

1097

1098

1099

Reinert H. K. \& Rupert Jr R. R. (1999) Impacts of translocation on behavior and survival of timber rattlesnakes, Crotalus horridus. J Herpetol 33, 45-61.

Rohr J. R., Schotthoefer A. M., Raffel T. R., Carrick H. J., Halstead N., Hoverman J. T., Johnson C. M., Johnson L. B., Lieske C. \& Piwoni M. D. (2008) Agrochemicals increase trematode infections in a declining amphibian species. Nature 455, 1235.

Rosenblum E. B., Poorten T. J., Joneson S. \& Settles M. (2012a) Substrate-specific gene expression in Batrachochytrium dendrobatidis, the chytrid pathogen of amphibians. PLoS ONE 7, e49924.

Rosenblum E. B., Poorten T. J., Settles M. \& Murdoch G. K. (2012b) Only skin deep: shared genetic response to the deadly chytrid fungus in susceptible frog species. Mol Ecol 21, 3110-20.

Rosenblum E. B., Poorten T. J., Settles M., Murdoch G. K., Robert J., Maddox N. \& Eisen M. B. (2009) Genome-wide transcriptional response of Silurana (Xenopus) tropicalis to infection with the deadly chytrid fungus. PLOS ONE 4, e6494.

Rowley J. J. \& Alford R. A. (2013) Hot bodies protect amphibians against chytrid infection in nature. Sci. Rep. 3, 1515.

Rowley J. J., Gleason F. H., Andreou D., Marshall W. L., Lilje O. \& Gozlan R. (2013) Impacts of mesomycetozoean parasites on amphibian and freshwater fish populations. Fungal Biol. Rev. 27, 100-11.

Roznik E. A., Sapsford S. J., Pike D. A., Schwarzkopf L. \& Alford R. A. (2015) Conditiondependent reproductive effort in frogs infected by a widespread pathogen. Proc. R. Soc. B 282, 20150694.

Salvador A., Veiga J. P., Martin J., Lopez P., Abelenda M. \& Puertac M. (1996) The cost of producing a sexual signal: testosterone increases the susceptibility of male lizards to ectoparasitic infestation. Behav Ecol 7, 145-50.

Sarmiento-Ramírez J. M., Abella E., Martín M. P., Tellería M. T., Lopez-Jurado L. F., Marco A. \& Diéguez-Uribeondo J. (2010) Fusarium solani is responsible for mass mortalities in nests of loggerhead sea turtle, Caretta caretta, in Boavista, Cape Verde. FEMS Microbiol. Lett. 312, 192-200.

Savage A. E. \& Zamudio K. R. (2011) MHC genotypes associate with resistance to a frog-killing fungus. Proceedings of the National Academy of Sciences 108, 16705-10. 
1100 Savage A. E. \& Zamudio K. R. (2016) Adaptive tolerance to a pathogenic fungus drives major histocompatibility complex evolution in natural amphibian populations. Proc. R. Soc. B 283, 20153115.

1103 Schall J. (1983) Lizard malaria: parasite-host ecology. In: Lizard ecology: studies of a model organism (eds J. Baker, R. Muller and D. Rollinson) pp. 84-100. Harvard University Press, Cambridge.

Schall J. J.(1982) Lizards infected with malaria: physiological and behavioral consequences. Science 217, 1057-9.

Schall J. J. (1986) Prevalence and virulence of a haemogregarine parasite of the Aruban whiptail lizard, Cnemidophorus arubensis. J Herpetol 20, 318-24.

Schall J. J. (1992) Parasite-mediated competition in Anolis lizards. Oecologia 92, 58-64.

Schall J. J., Bennett A. F. \& Putnam R. W. (1982) Lizards infected with malaria: physiological and behavioral consequences. Science 217, 1057-9.

Schall J. J. \& Sarni G. A. (1987) Malarial parasitism and the behavior of the lizard, Sceloporus occidentalis. Copeia 1987, 84-93.

Schall J. J. \& Vogt S. P. (1993) Distribution of malaria in Anolis lizards of the Luquillo Forest, Puerto Rico: implications for host community ecology. Biotropica 25, 229-35.

Scheele B. C., Hunter D. A., Grogan L. F., Berger L., Kolby J. E., McFadden M. S., Marantelli G., Skerratt L. F. \& Driscoll D. A. (2014) Interventions for Reducing Extinction Risk in chytridiomycosis-threatened amphibians. Conserv Biol 28, 1195-205.

Schotthoefer A. M., Cole R. A. \& Beasley V. R. (2003) Relationship of tadpole stage to location of echinostome cercariae encystment and the consequences for tadpole survival. $J$ Parasitol 89, 475-82.

Sears B., Snyder P. \& Rohr J. (2013) Infection deflection: hosts control parasite location with behaviour to improve tolerance. Proceedings of the Royal Society of London B: Biological Sciences 280, 20130759.

Session A. M., Uno Y., Kwon T., Chapman J. A., Toyoda A., Takahashi S., Fukui A., Hikosaka A., Suzuki A. \& Kondo M. (2016) Genome evolution in the allotetraploid frog Xenopus laevis. Nature 538, 336.

Sherman E. (2008) Thermal biology of newts (Notophthalmus viridescens) chronically infected with a naturally occurring pathogen. $J$ Therm Biol 33, 27-31. 
1131 Shilton C., Brown G., Benedict S. \& Shine R. (2008) Spinal arthropathy associated with Ochrobactrum anthropi in free-ranging cane toads (Chaunus [Bufo] marinus) in Australia. Vet Pathol 45, 85-94.

1134 Shine R. (2010) The ecological impact of invasive cane toads (Bufo marinus) in Australia. The Quarterly Review of Biology 85, 253-91.

1136 Siddall M.E. \& Desser S. S. (1992) Alternative leech vectors for frog and turtle trypanosomes. The Journal of parasitology 78, 562-3.

Sih A., Spiegel O., Godfrey S., Leu S. \& Bull C. M. (2017) Integrating social networks, animal personalities, movement ecology and parasites: a framework with examples from a lizard. Anim Behav 136, 195-205.

Sin H., Beard K. H. \& Pitt W. C. (2008) An invasive frog, Eleutherodactylus coqui, increases new leaf production and leaf litter decomposition rates through nutrient cycling in Hawaii. Biol Invasions 10, 335-45.

Smith Trail D. R. (1980) Behavioral interactions between parasites and hosts: host suicide and the evolution of complex life cycles. Am. Nat. 116, 77-91.

Soliman M. (2012) Heavy metal pollution across sites affecting the intestinal helminth communities of the Egyptian lizard, Chalcides ocellatus (Forskal, 1775). Environ Monit Assess 184, 7677-85.

Sorci G., Clobert J. \& Michalakis Y. (1996) Cost of reproduction and cost of parasitism in the common lizard, Lacerta vivipara. Oikos, 121-30.

Sorci G., Massot M. \& Clobert J. (1994) Maternal parasite load increases sprint speed and philopatry in female offspring of the common lizard. Am. Nat. 144, 153-64.

Speare R., Berger L., O'Shea P., Ladds P. \& Thomas A. (1997) Pathology of mucormycosis of cane toads in Australia. $J$ Wildl Dis 33, 105-11.

Speare R., Thomas A., O'Shea P. \& Shipton W. (1994) Mucor amphibiorum in the toad, Bufo marinus, in Australia. $J$ Wildl Dis 30, 399-407.

Spurgin L. G. \& Richardson D. S. (2010) How pathogens drive genetic diversity: MHC, mechanisms and misunderstandings. Proceedings of the Royal Society of London B: Biological Sciences 277, 979-88. 
1160 Stenos J., Graves S., Popov V. L. \& Walker D. H. (2003) Aponomma hydrosauri, the reptileassociated tick reservoir of Rickettsia honei on Flinders Island, Australia. The American journal of tropical medicine and hygiene 69, 314-7.

1163 Stopper G. F., Hecker L., Franssen R. A. \& Sessions S. K. (2002) How trematodes cause limb deformities in amphibians. Journal of Experimental Zoology Part A: Ecological Genetics and Physiology 294, 252-63.

Sun Y.-B., Xiong Z.-J., Xiang X.-Y., Liu S.-P., Zhou W.-W., Tu X.-L., Zhong L., Wang L., Wu D.-D. \& Zhang B.-L. (2015) Whole-genome sequence of the Tibetan frog Nanorana parkeri and the comparative evolution of tetrapod genomes. Proceedings of the National Academy of Sciences 112, E1257-E62.

Szuroczki D. \& Richardson J. M. (2012) The behavioral response of larval amphibians (Ranidae) to threats from predators and parasites. PLOS ONE 7, e49592.

Taggart P. L., Leu S. T., Spiegel O., Godfrey S. S., Sih A. \& Bull C. M. (2018) Endure your parasites: sleepy lizard movement is not affected by their ectoparasites. Can J Zool.

Taylor C. N., Oseen K. L. \& Wassersug R. J. (2004) On the behavioural response of Rana and Bufo tadpoles to echinostomatoid cercariae: implications to synergistic factors influencing trematode infections in anurans. Can J Zool 82, 701-6.

1179 Teacher A.G., Garner T. W. \& Nichols R. A. (2009) Evidence for directional selection at a novel major histocompatibility class I marker in wild common frogs (Rana temporaria) exposed to a viral pathogen (Ranavirus). PLoS ONE 4, e4616.

Teacher A., Cunningham A. \& Garner T. (2010) Assessing the long-term impact of ranavirus infection in wild common frog populations. Anim Conserv 13, 514-22.

Tocque K. (1993) The relationship between parasite burden and host resources in the desert toad (Scaphiopus couchii), under natural environmental conditions. J Anim Ecol, 683-93. 
1190 Tompkins D. M., Carver S., Jones M. E., Krkošek M. \& Skerratt L. F. (2015) Emerging infectious diseases of wildlife: a critical perspective. Trends Parasitol 31, 149-59.

1192 Uhrig E. J., Spagnoli S. T., Tkach V. V., Kent M. L. \& Mason R. T. (2015) Alaria mesocercariae 1193 in the tails of red-sided garter snakes: evidence for parasite-mediated caudectomy. Parasitol Res 114, 4451-61.

Václav R.,Prokop P. \& Fekiač V. (2007) Expression of breeding coloration in European Green Lizards (Lacerta viridis): variation with morphology and tick infestation. Can J Zool 85, 1199-206.

Van Rooij P., Martel A., Haesebrouck F. \& Pasmans F. (2015) Amphibian chytridiomycosis: a

Venesky M. D.,Parris M. J. \& Storfer A. (2009) Impacts of Batrachochytrium dendrobatidis review with focus on fungus-host interactions. Vet Res 46, 137. infection on tadpole foraging performance. EcoHealth 6, 565-75.

Viggers K., Lindenmayer D. \& Spratt D. (1993) The importance of disease in reintroduction programmes. Wildl Res 20, 687-98.

Voyles J., Young S., Berger L., Campbell C., Voyles W. F., Dinudom A., Cook D., Webb R., Alford R. A. \& Skerratt L. F. (2009) Pathogenesis of chytridiomycosis, a cause of catastrophic amphibian declines. Science 326, 582-5.

Wang S., Liu C., Wilson A. B., Zhao N., Li X., Zhu W., Gao X., Liu X. \& Li Y. (2017) Pathogen richness and abundance predict patterns of adaptive MHC variation in insular amphibians. Mol Ecol Volume26, 4671-85.

Wheeler E., Hong P.-Y., Bedon L. C. \& Mackie R. I. (2012) Carriage of antibiotic-resistant enteric bacteria varies among sites in Galapagos reptiles. J Wildl Dis 48, 56-67.

1212 Whiley H., Custance G., Graves S., Stenos J., Taylor M., Ross K. \& Gardner M. G. (2016) Rickettsia detected in the reptile tick Bothriocroton hydrosauri from the lizard Tiliqua rugosa in South Australia. Pathogens 5, 41.

1215 Whiley H., Gardner M. G. \& Ross K. (2017) A review of Salmonella and squamates (lizards, 1216 snakes and amphisbians): implications for public health. Pathogens 6, 38.

1217 Whiteman N. K., Matson K. D., Bollmer J. L. \& Parker P. G. (2006) Disease ecology in the 1218 Galapagos Hawk (Buteo galapagoensis): host genetic diversity, parasite load and natural 1219 antibodies. Proceedings of the Royal Society of London B: Biological Sciences 273, 7971220 804. 
1221 Woodhams D. C., Bosch J., Briggs C. J., Cashins S., Davis L. R., Lauer A., Muths E., Puschendorf R., Schmidt B. R. \& Sheafor B. (2011) Mitigating amphibian disease: strategies to maintain wild populations and control chytridiomycosis. Front Zool 8, 8.

1224
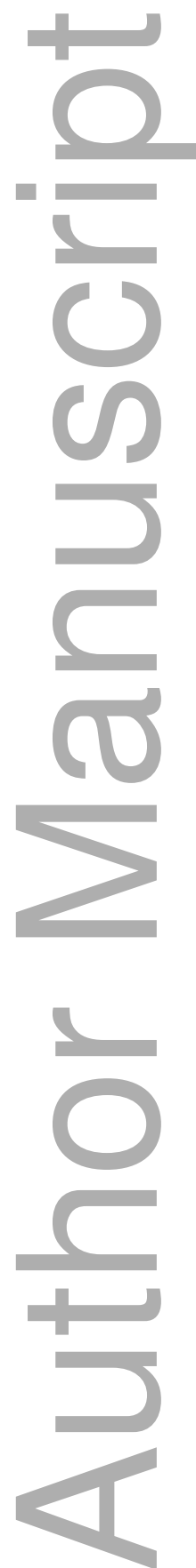


\section{University Library}

\section{- M M N E R VA A gateway to Melbourne's research publications}

Minerva Access is the Institutional Repository of The University of Melbourne

\section{Author/s:}

Bower, DS;Brannelly, LA;McDonald, CA;Webb, RJ;Greenspan, SE;Vickers, M;Gardner, MG;Greenlees, MJ

Title:

A review of the role of parasites in the ecology of reptiles and amphibians

Date:

2019-05-01

\section{Citation:}

Bower, D. S., Brannelly, L. A., McDonald, C. A., Webb, R. J., Greenspan, S. E., Vickers, M., Gardner, M. G. \& Greenlees, M. J. (2019). A review of the role of parasites in the ecology of reptiles and amphibians. AUSTRAL ECOLOGY, 44 (3), pp.433-448. https://doi.org/10.1111/ aec.12695.

Persistent Link:

http://hdl.handle.net/11343/285081 